\title{
0 pós-abolição e suas dinâmicas de sociabilidade: lógicas familiares e relações interpessoais no oeste paulista cafeeiro ${ }^{*}$
}

\author{
Rogério da Palma** \\ Oswaldo Mário Serra Truzzi ${ }^{* * *}$
}

Tomando como foco o município de São Carlos, um dos principais centros da economia cafeeira do oeste paulista durante a virada do século XIX para o XX, o artigo analisa as tensões presentes nas relações interpessoais tecidas entre negros, de um lado, e fazendeiros e pequenos proprietários rurais, de outro. Por meio da leitura de dois inquéritos policiais da época, percebeu-se que essas relações eram mediadas por determinados códigos morais, os quais, por sua vez, delimitavam certas normas de sociabilidade. Quando alguns destes códigos eram quebrados, as situações de conflito se potencializavam. Pode-se afirmar que, se a proximidade com pessoas de posse ainda era, para a população negra do pós-abolição, uma das principais fontes para obtenção de recursos materiais e simbólicos, as relações de poder inscritas nesses vínculos não deixavam de produzir contestações quanto às identificações e hierarquias encerradas no âmbito familiar. De modo geral, acredita-se que as disputas de poder presentes nessas interações podem estar relacionadas à renegociação, trazida pelo fim do escravismo, de determinadas formas de distinção social.

Palavras-chave: Família escrava. Pós-abolição. Hierarquias familiares. Sociabilidades. Economia cafeeira. Interior paulista.

\footnotetext{
* O presente trabalho foi desenvolvido com auxílio da Fapesp, que outorgou bolsa de doutorado ao primeiro autor e também apoiou o projeto temático "Observatório das Migrações em São Paulo - fases e faces do fenômeno migratório", coordenado por Rosana Baeninger. Agradecemos à Fundação Pró-Memória de São Carlos e a seus funcionários pelo acesso aos processos criminais aqui utilizados. Somos também gratos a Barbara Weinstein e Karl Monsma pelos comentários oferecidos por ocasião da apresentação de versão anterior deste trabalho no 36th Annual Meeting of the Social Science History Association, em Boston, ocorrido em 2011.

** Programa de Pós-Graduação em Sociologia da Universidade Federal de São Carlos (UFSCar), São Carlos-SP, Brasil (rog.cs@hotmail.com).

${ }^{\star \star \star}$ Universidade Federal de São Carlos (UFSCar), São Carlos-SP, Brasil (truzzi@ufscar.br).
} 


\section{Introdução}

Alguns anos após o lançamento de A integração do negro na sociedade de classes (1978), um dos principais livros de Florestan Fernandes, ${ }^{1}$ surgiu uma série de estudos contestando a validade de vários relatos e argumentações feitos pelo autor ao longo da obra. Nas décadas de 1980 e 1990, pesquisas de diversos historiadores (SLENES, 1999; ANDREWS, 1998; CHALHOUB, 1990; CASTRO, 1997) revelaram resultados que contrariavam algumas afirmações de Fernandes, das quais, a principal referia-se ao fato de a população negra, segundo o sociólogo, ter herdado das relações escravistas um baixo imperativo cultural quanto à formação de unidades familiares e de laços sociais duradouros. De acordo com estas pesquisas, longe de estarem "perdidos uns dos outros", conforme escreveu Fernandes, os negros que vivenciaram as últimas décadas da escravidão e os primeiros anos pós-1888 não somente formaram sólidas redes de relações interpessoais, como também estas foram essenciais nas estratégias e caminhos adotados por eles após sua saída do cativeiro. A consolidação de projetos familiares e de alianças com senhores e homens livres, assim como com outros escravos, teria sido fundamental, nos mais variados contextos, para as trajetórias que ligavam a escravidão à liberdade.

As relações pessoais constituídas ainda durante o período da escravidão foram peçaschave na renegociação do estatuto social dos ex-escravos durante o período posterior à abolição do regime servil. A inserção em outras relações de trabalho, a nova posição de cidadãos diante da esfera do Estado, a redefinição de determinadas formas de convívio, suas relações peculiares com o tempo e seus planos de mobilidade - ou seja, tudo o que envolvia um projeto maior de liberdade ${ }^{2}$ - passavam pela intermediação da teia de vínculos estabelecida com outros agentes sociais. Inserindo-se neste debate, o presente artigo pretende, por meio da análise de dois inquéritos policiais, ${ }^{3}$ abordar algumas das tensões e ambiguidades presentes nas redes de relações interpessoais tecidas por alguns negros dentro da conjuntura do oeste paulista cafeeiro da virada do século XIX para o XX. Fala-se em ambiguidade porque o exame de tais inquéritos mostrou que as redes de relações pessoais,

\footnotetext{
${ }_{1}^{1}$ A primeira publicação deste livro data de 1965 , sendo que ele foi originalmente apresentado como tese de cátedra em Sociologia na Universidade de São Paulo.

${ }^{2}$ Ao longo de suas experiências, escravos e libertos construíram uma série de concepções de liberdade, que variavam de acordo com a conjuntura, mas quase sempre passaram por uma disputa em torno da atribuição de sentidos a conceitos como trabalho, raça, cidadania, mobilidade, etc. A liberdade, desse modo, não pode ser encarada como um valor absoluto e totalmente dissociado da escravidão, mas sim como um ideal construído a partir das diversas apropriações realizadas sobre a sua própria definição. Para uma discussão mais aprofundada sobre os significados da liberdade para os ex-escravos em diferentes contextos, ver Cooper, Holt e Scott (2005).

${ }^{3}$ Há um corpo crescente de literatura que justifica a adoção e o estudo de casos no processo de produção de conhecimento em ciências sociais. De modo breve, é possível dizer que casos podem se constituir como parte essencial do processo de produzir descrições teoricamente estruturadas da vida social e, ao mesmo tempo, de usar evidências empíricas para articular teorias. Os casos aqui descritos pretendem servir a ambas as perspectivas: de um lado, usar a teoria para dar sentido às evidências empíricas contidas nos inquéritos; de outro, também utilizar tais evidências dos inquéritos com o objetivo de refinar certas teorias. Para um aprofundamento do tema, consultar a coletânea de artigos organizada por Ragin e Becker (1992). Sobre a utilização dos inquéritos policiais, cabe ressaltar que tal documentação, juntamente com os processos criminais, foi assiduamente empregada como fonte nas pesquisas acerca das experiências de escravos e libertos (LARA, 1988; CHALHOUB, 1990; CASTRO, 1995; MONSMA, 2005a, 2005b).
} 
por um lado, permitiam a adoção de certas estratégias familiares, mas, por outro, poderiam colocar em xeque a lógica familiar que sustentava estas próprias estratégias. Ao manterem laços de compadrio/afinidade com fazendeiros ou pequenos proprietários, negros e negras acabavam por colocar em disputa referenciais hierárquicos que se encontravam anteriormente circunscritos às interações familiares. Os embates em torno desses referenciais, por seu turno, exacerbavam a existência de códigos morais na mediação dessas relações, os quais, muitas vezes, poderiam estar implicitamente ligados à questão da redefinição do estatuto social dos ex-escravos durante o pós-abolição.

\section{Entre o favor e a (in)gratidão: o assassinato de José Bueno do Prado}

Na historiografia sobre as últimas décadas da escravidão, é fácil se deparar com estudos que apontam para a formação de vínculos entre senhores e escravos. No que se refere às fazendas cafeeiras de São Paulo, Slenes (1997, p. 271) afirma não ser incomum o fato de as relações de compadrio ultrapassarem, por vezes, os limites do cativeiro. ${ }^{4}$ Isso demonstraria a necessidade de, num mundo hostil, os escravos criarem laços morais com pessoas de recursos, visando sua proteção e a de seus filhos. Segundo o autor, os senhores de escravos do oeste paulista impunham seu poder não somente pela força, mas também por meio da distribuição de “favores”. Os proprietários instituíam, juntamente com a ameaça e a coação, um sistema diferencial de incentivos. A proposta dessas ações, na percepção de Slenes, era tornar os escravos cada vez mais dependentes por meio de obrigações morais. Melhores condições de trabalho, maiores chances de se conseguir alforria e a atenuação dos castigos físicos eram "privilégios" dos escravos que mantinham boas relações com seus proprietários.

A distribuição de prêmios por "mérito" entre os cativos fazia com que eles ficassem subordinados a seus próprios projetos domésticos, pois as chances de melhorar de vida estavam atreladas aos laços de lealdade com seus superiores. Tal situação, todavia, nem sempre acabava trazendo apenas benefícios. Se esses cativos gozavam dos favores dos fazendeiros, ao mesmo tempo não podiam dispensar a amizade de seus parceiros escravos, devido ao receio de sofrerem atitudes de revanchismo. Os relacionamentos com outros cativos, desse modo, não podiam ser dispensados nem mesmo por aqueles que desfrutavam dos benefícios advindos dos senhores. ${ }^{5}$ Os escravos do oeste paulista viviam, de acordo com Slenes, em um mundo de força e de favor, precisando tomar o máximo de cuidado na construção de suas redes de afinidades e de preferências. A escolha de parceiros e a execução

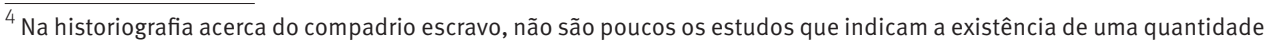
diminuta de casos em que o senhor foi o padrinho direto de um escravo. Essa tendência baseia-se na hipótese de que o papel de senhor, voltado para a disciplinarização do escravo, seria incompatível com o papel de padrinho, mais caracterizado por ser uma figura protetora. Tal premissa, todavia, considera essas características mutuamente exclusivas, quando, na realidade, como ficará mais claro adiante, perpassam determinadas formas de controle nas relações de compadrio. Proteger, em muitos casos, não deixa de significar controle/disciplinarização. Para uma breve análise da historiografia sobre o compadrio escravo, consultar Bacellar (2011).

${ }^{5}$ As alianças com outros negros também poderiam ser de grande relevância para escravos e libertos. Como o objetivo desse artigo é refletir sobre as relações de poder que atravessavam os vínculos interpessoais, resolveu-se, todavia, priorizar a análise dos laços mantidos por negros(as) com fazendeiros ou mesmo com pequenos proprietários.
} 
de estratégias de vida nem sempre eram compatíveis, dando às relações de sociabilidade desses sujeitos um caráter imprevisível.

Os laços firmados com pessoas de posse e as potenciais tensões trazidas pelas relações de poder inscritas na constituição desses vínculos parecem ter persistido na trajetória de alguns negros do oeste paulista mesmo após a abolição. ${ }^{6}$ É o que fica evidente na análise de alguns inquéritos policiais processados no município de São Carlos. ${ }^{7}$ Em 29 de março de 1901, por exemplo, João de Sampaio Leite, pardo, 40 anos, alfabetizado, natural de Campinas, assassinou, com uma navalha, o seu amigo José Bueno do Prado, 50 anos, casado, lavrador, natural de Brotas. Mariano Martins, concunhado de José Bueno, foi quem o socorreu, conduzindo João de Sampaio à polícia. No seu depoimento, consta o seguinte relato.

Que hontem depois do jantar, em casa do seu concunhado José Bueno do Prado, no bairro do Can-can deste município, elle conductor levantou-se da meza e dirigio-se para o serviço que pouco depois de lá chegar, ouvio gritos de socorro que reconheceu serem da mulher do seu concunhado e voltou incontinente para a casa de José Bueno, para ver o que ocorria, que ao chegar elle conductor vio José Bueno cahido por terra, ferido e com as tripas de fora, dizendo-lhe o offendido que fora João de Sampaio Pinto, vulgo João Machinista, quem o offendera; que nesse momento elle conductor vio que João de Sampaio Pinto, ainda armado de navalha tentava fugir e então reunio-se com Julio de Lamano e Joaquim Antonio da Silva, sahindo ao encalço de João Machinista, o agressor, e conseguindo prendel-o, sendo para isso preciso deu-lhe umas cacetadas [...] (Inquéritos policiais. Fundação Pró-Memória de São Carlos, caixa 199, n. 118, 1901).

Antes de falecer em decorrência dos ferimentos sofridos, José Bueno conseguiu prestar depoimento e discorrer um pouco acerca da relação que tinha com o seu agressor. Segundo ele, o réu "morava de favor" em seu sítio, juntamente com os dois filhos, Sebastião e Henrique. O último, inclusive, "João Pinto entregara aos cuidados delle depoente”. João Sampaio morava provisoriamente na sua propriedade, pois estava esperando a época da colheita para se empregar como maquinista em alguma fazenda. ${ }^{8}$ José Bueno ressaltou ainda que, mais ou menos há quinze dias, precisou interromper uma briga do acusado com Sebastião, pois o primeiro tentava matar o filho. Decidiu, então, separar os dois de quarto, passando João Sampaio a dormir na sala. José Bueno afirmou ter intermediado, no dia em que foi atacado pelo réu, novo atrito entre o pai e o mesmo filho, porém desta vez expulsou João Sampaio de sua casa. A partir dessa sua atitude, o réu teria usado uma navalha para cortá-lo. A vítima finalizou seu depoimento mencionando não nutrir nenhum tipo de inimizade com seu ofensor; ao contrário, sempre procurava protegê-lo.

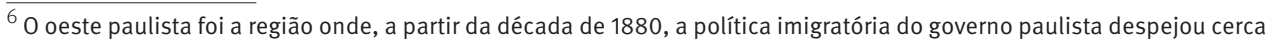
de dois milhões de imigrantes (ANDREWS, 2007, p. 171). É de se acreditar que, com a competitividade de trabalhadores que usufruíam de uma melhor imagem diante da opinião pública, os recursos relacionais fossem até mais valorizados pelos negros depois de abolida a escravidão.

7 São Carlos é uma típica região cafeeira do "novo" oeste paulista, iniciando o plantio de grandes quantidades de café por volta da metade do século XIX, ainda com a utilização de escravos. Posteriormente, consolidou sua produção com a chegada de trabalhadores estrangeiros, sendo um dos municípios da região que mais receberam imigrantes durante a virada do século XIX para o XX. Para uma consulta à história de São Carlos, ver Truzzi (2000) e Truzzi e Bassanezi (2009). ${ }^{8} \mathrm{O}$ maquinista era aquele que trabalhava com a máquina de beneficiamento dos grãos de café.
} 
O filho com quem João Sampaio discutia, Sebastião Pinto de Sampaio, 20 anos, operário, solteiro, natural de São Carlos, disse em seus esclarecimento perante o juiz que seu pai falava alto no meio da discussão porque “elle depoente é meio surdo”. José Bueno, assustado com os gritos proferidos por seu pai, veio perguntar o que estava acontecendo. João Sampaio, por seu turno, teria respondido “não é nada, é negócio de família”. José Bueno então puxara seu pai pelas orelhas e o arrancara do quarto, momento em que este sacou uma navalha e cortou-o. Por fim, Sebastião afirmou nunca ter presenciado nenhuma espécie de discussão entre seu pai e José Bueno. João Sampaio foi, no entanto, condenado a dez anos e seis meses de prisão. Seu advogado ainda tentou recorrer da decisão, mas o Tribunal manteve a pena.

A frase proferida por João Sampaio no instante em que José Bueno procurava estar a par da situação - "é negócio de família" - demonstra um discernimento do maquinista acerca dos seus laços afetivos: as relações familiares não se confundiam com os outros vínculos, mesmo que estes fornecessem alguma espécie de auxílio e chegassem até o estado de coabitação. Embora morasse “de favor” na casa de José Bueno, bem como tivesse entregado seu filho mais novo "aos cuidados" do próprio, ele não o considerava parte de sua família e, por isso, não aceitava as interferências em sua autoridade de pai.

Estudando as relações familiares das classes populares cariocas durante o pós-abolição, nas quais estavam inseridos muitos libertos e seus descendentes diretos, Chalhoub (2001, p. 175-176) encontrou dificuldades em estabelecer os significados que este grupo atribuía ao termo "família”. De acordo com suas conclusões, esses indivíduos se envolviam em redes de solidariedade e de ajuda mútua muito extensas, o que dificultou a identificação dos limites entre as redes de solidariedade ditas "familiares" e as de outro tipo, tais como as relações de compadrio, por exemplo. Fonseca (1990, p. 33), ao analisar os processos de "Apreensão de Menores" em Porto Alegre, entre 1901 e 1926, surpreendeu-se com o grande número de "crianças em circulação", isto é, que não viviam com os pais, bem como de adultos que diziam ter passado vários anos de sua infância nas mesmas condições.

Cabe sublinhar aqui o fato de que a noção conjugal/individualista de família é uma invenção da modernidade. Anteriormente ao que se convencionou a chamar de "época moderna”, período correspondente na Europa ao pós-século XVIII, as sociabilidades familiares mal se distinguiam dos laços de vizinhança, comunitários e "públicos". A sociabilidade conjugal e individualista remete à ideia burguesa de família, a qual se vincula, por sua vez, à produção dos sentimentos de intimidade/privacidade (ARIÉS, 1981). Essa noção de família enquanto conjunto de vínculos distinto dos outros laços afetivos expandiu-se para diversos lugares do mundo, ganhando variados contornos em diferentes conjunturas. É essa percepção de família, por exemplo, que as políticas públicas das principais cidades brasileiras, por meio da propagação de agentes sanitários e de forças jurídico-policiais, esforçavam em impor para as camadas populares durante o início do século XX.

É de fundamental importância atingir como alvo privilegiado e seguro esta construção imaginária da sociedade moderna: a família nuclear. A casa deve constituir um novo espaço normalizado de relações estáveis, naturalizadas e assépticas, onde podem se aprofundar os sentimentos familiares 
e estreitarem-se os vínculos entre os membros da família [...] As investidas sanitárias apontam a higiene das habitações populares como o meio mais eficaz para erradicar a raiz do problema (infecções e moléstias contagiosas) e recuperar a saúde dos desfavorecidos. Desaglomerar os pobres, arejar e iluminar os compartimentos e eliminar miasmas e germes, observando a mais rigorosa higiene constituem tecnologias disciplinares do poder médico. Tática de antiaglomeração: primeiro passo para a formação do sentimento de intimidade e da sedução pela propriedade privada (RAGO, 1985, p. 42).

Alguns estudos (CAULFIELD, 2000; ESTEVES, 1989) ressaltam o caráter moralizador presente nos projetos republicanos, chamando a atenção, contudo, para os limites em se impor uma moralidade familiar única. De acordo com estes trabalhos, principalmente quando se observa o comportamento das chamadas "classes populares", é difícil perceber um modelo único de relações familiares, mas isso não significa dizer que tais relações pareciam indiscerníveis. Pelo menos no que diz respeito ao caso anteriormente descrito, era operacionalizada uma hierarquização entre os papéis sociais inscritos nas relações pessoais: o papel de pai de João Sampaio não poderia, na percepção dele, sofrer a interferência de um amigo/compadre. A gramática social inscrita nesses papéis, cabe lembrar, possui um caráter dinâmico, sendo os seus conteúdos constantemente renegociados segundo as interações que são estabelecidas. O que se procura demonstrar aqui, no entanto, é que, na visão de João Sampaio, havia uma nítida distinção entre os vínculos e reciprocidades encerrados na lógica familiar, por um lado, e aqueles referentes a outros tipos de relações interpessoais, por outro.

Segundo Fonseca (1990, p. 33), dadas as circunstâncias específicas do Brasil, “a unidade mãe-pai-filhos não se apresenta bem delimitada, autocontida. As necessidades, tanto materiais quanto afetivas, de seus membros são com frequência satisfeitas por pessoas alheias a esse núcleo". Não era raro, durante a virada do século XIX para o XX, encontrar famílias de ex-escravos morando no mesmo espaço doméstico com outras famílias, seja em fazendas ou em propriedades rurais menores. ${ }^{9}$ João Sampaio conseguiu auxílio na casa do proprietário de um sítio, para o qual, inclusive, entregou os cuidados de seu filho mais novo. Considerando o caso, pode-se sugerir que, para ele, aparecia como algo interessante para o filho ficar mais próximo de um pequeno proprietário rural do que dele próprio, um maquinista que perambulava de fazenda em fazenda à procura de emprego. ${ }^{10} \mathrm{~A}$ ligação pessoal de João Sampaio com José Bueno foi, portanto, fundamental para o primeiro: ele, um trabalhador temporário da economia cafeeira, ${ }^{11}$ conseguiu, por meio de sua amizade com o proprietário de um sítio, além de um abrigo para a família em um momento em que se encontrava desempregado, estender esses laços para o benefício do filho mais novo. No

\footnotetext{
${ }_{9}^{9}$ Para mais informações acerca das estratégias de compadrio entre os cativos do oeste paulista, ver Slenes (1997). Sobre a utilização de estratégias "paternalistas” dos negros situados nas fazendas de São Carlos durante o pós-abolição, consultar Medeiros (2005).

${ }^{10}$ Fonseca (1990 e 2004) argumentou que a instabilidade no emprego masculino repercutia sobre as dinâmicas familiares em grupos populares, no sentido de "precarizar" laços conjugais e aumentar o número de crianças em circulação.

${ }^{11}$ Muitos negros que permaneceram trabalhando nas fazendas de café após a chegada massiva de imigrantes passaram a ocupar empregos subsidiários, sendo chamados para trabalhar somente em determinados períodos do ano agrícola. Para mais informações sobre essa situação, ver Holloway (1984) e Vangelista (1991).
} 
seu depoimento, todavia, José Bueno relatou, indiretamente, a hierarquia que predominava na sua relação com João Sampaio. Ao dizer "que sempre procurava proteger o réu” e que o mesmo morava de "favor" na sua casa, José Bueno deixa implícito uma suposta gratidão que João Sampaio deveria nutrir em relação a ele. A reciprocidade inscrita no binômio favor/ gratidão demonstra o complexo jogo de poder que mediava esse tipo de relacionamento, em que qualquer leitura equivocada das regras de convivência estabelecidas poderia terminar em conflito.

Analisando o desenvolvimento do conceito de capital social - entendido como a capacidade dos indivíduos em garantir benefícios advindos da sua localização em redes sociais -, Portes (1998, p. 15) destaca o fato de essa noção sugerir não somente as consequências positivas da sociabilidade, mas também o caráter normativo e excludente presente nos recursos relacionais. Isso porque os vínculos sociais, ao criarem certos laços de sociabilidade entre um grupo de pessoas, permitem a circulação de formas de controle social e, além disso, pressupõem a exclusão de outros indivíduos. 0 alcance das potenciais garantias e obrigações implícitas nas relações interpessoais depende, por seu turno, da quantidade, do conteúdo e da intensidade dos laços que ligam o conjunto delimitado de indivíduos (PORTES, 1995, p. 9). No caso das análises sobre as alianças de compadrio estabelecidas por escravos e libertos, são poucos os estudos que procuram enfatizar os potenciais custos implícitos nas relações de poder sob as quais se firmavam os vínculos com homens livres, senhores e demais pessoas com posses.

Essa ligação estreita pode representar, de determinado ponto de vista, uma linha muito tênue atravessando as relações familiares e as relações de amizade e compadrio. Contudo, João Sampaio possuía discernimento bem claro das suas relações de parentesco e da sua identificação enquanto pai. Seus vínculos pessoais com uma pessoa de certa posse não significavam a continuidade de determinadas relações familiares. Sua relação com José Bueno possibilitou auxílio a toda a sua família, mas também significou o enfraquecimento de uma moralidade que o descrevia enquanto pai, haja vista o fato de o proprietário do sítio se sentir no direito de mediar a relação de João Sampaio com os seus filhos. Este último, muito provavelmente, interpretou a interferência de José Bueno na discussão que tinha com seu filho como uma intromissão, a qual poderia minar sua autoridade de pai.

\section{As contendas nas relações de compadrio: o caso envolvendo Lusia, Ozoria e a família Camargo}

O fato de alguns negros entregarem os cuidados de seus filhos a pessoas próximas não significava o abandono da gramática moral relacionada a certos papéis familiares. É o que deixa implícito o exame de outro inquérito, cujos réus são Gabriel Dionisio da Silva, preto, 30 anos, carroceiro, solteiro, natural da Bahia, e "Cancio", espanhol, administrador. ${ }^{12}$ Na noite de 25 de março de 1893, Lusia Ignacia do Espírito Santo, preta, 32 anos, solteira, natural da

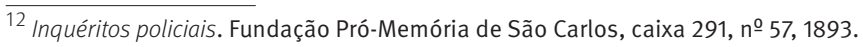


Bahia, convidou Gabriel para ir até uma fazenda vizinha, juntamente com mais dois homens, para buscar a filha dela. Chegando ao local, próximo à sede da fazenda, Lusia disse para eles esperarem ali enquanto ela encontrava sua filha. Passados alguns instantes, Lusia voltou correndo aos gritos e pedindo para eles fugirem. O grupo então se dispersou no meio do cafezal. Gabriel se refugiou embaixo de uma árvore e foi avistado por Cancio, o administrador da fazenda. Indagado sobre o que fazia naquele local, ele teria dito que "estava passeando". Cancio o advertiu afirmando não ser o horário e nem o lugar para passear, ordenando-lhe ir embora antes que "levasse fogo". Diante de tal situação, Gabriel retrucou dizendo "fogo por fogo aqui também tem” e, em seguida, armou uma espingarda que carregava consigo e disparou. Sua arma, porém, falhou, dando oportunidade para Cancio desfechar-lhe dois tiros. Gabriel foi socorrido pelos seus companheiros e levado para o hospital da cidade, onde recebeu a notícia de que tinha ficado cego de um olho. No julgamento, tanto Cancio como Gabriel foram absolvidos.

Devemos nos concentrar aqui no motivo que levou Gabriel a se dirigir a tal fazenda no meio da noite, ou seja, a investida de Lusia para trazer sua filha. Segundo o depoimento do proprietário da fazenda, Rocha Camargo Arruda, 50 anos, lavrador, casado, natural de Campinas, Lusia tinha “dado” a filha para a mulher dele, há cerca de um ano, com a intenção de a menina aprender serviços domésticos. Por volta de oito dias atrás, entretanto, a mãe da jovem tentou levá-la de volta, sem avisar o fazendeiro, mas a filha de Lusia não aceitou ir com a mãe sem o consentimento da "madrinha". Rocha revelou ter conversado com Lusia na ocasião, que manifestou o desejo de levar a filha de volta, pois já havia arranjado casamento para a menina. Ele, por sua vez, adiantou que, se fosse esse o caso, bastaria Lusia trazer todos os papéis referentes ao matrimônio. Sendo assim, Rocha até ajudaria no casamento. O fazendeiro diz ter comunicado um juiz sobre a situação, sendo autorizado por ele a permanecer com a jovem em casa. Lusia, quando interrogada, admitiu a versão de Rocha. O motivo de sua pretensão em tirar a filha das guardas da família do fazendeiro seria o boato de alguns de seus amigos, que disseram "que a menina podia lá se perder". Ela afirmou também ter procurado a Justiça e manifestado seu desejo de tirar a filha daquela fazenda. O juiz teria revelado a ela a necessidade de arranjar o noivo e dar entrada nos papéis para, posteriormente, ele poder mandar buscar a jovem. Algumas pessoas, porém, contaram para Lusia que sua filha, mesmo tendo 15 anos, não tinha o direito de se casar. De “cabeça quente", ela resolveu então "furtar" a própria filha. Chegando à fazenda onde se encontrava a filha, Lusia foi surpreendida pelo administrador e saiu correndo assustada, o que culminou no conflito citado. O pivô do episódio, Ozoria Maria da Conceição, 15 anos, "serviços domésticos", natural da Bahia, relatou estar satisfeita na casa de Rocha, não pretendendo deixar sua "madrinha" para voltar a morar com sua mãe, visto "que o que sabe deve tudo a senhora deste [a mulher de Rocha]".

Um dos aspectos relacionados à prática de deixar os cuidados de filhos a "compadres" era o de que, como sugerido na análise do inquérito anterior, diversos negros tinham como ideia fazer seus filhos aprenderem um trabalho capaz de propiciar-lhes melhores oportunidades. No 
caso específico deste último inquérito, percebe-se o interesse de Lusia em, se não que a filha aprendesse um tipo de trabalho diferente do seu, pois a menina realizava apenas serviços domésticos na casa do fazendeiro, pelo menos que ela pudesse aproveitar as afinidades com uma família de fazendeiros. Tal vínculo de intimidade, todavia, deixou Ozoria suscetível a certas relações de dependência para com a família em questão. Lusia, tão logo soube que a filha poderia "se perder"13 na casa do fazendeiro, tratou de operacionalizar o que ela entendia ser o seu papel de mãe. Buscando resguardar a "honra” da filha, ela empenhou-se em tentar controlar a sexualidade da mesma, arranjou-lhe casamento e fez de tudo para a filha sair da proteção do fazendeiro.

As disputas travadas por Lusia e Rocha Camargo em torno da guarda de Ozoria podem revelar indícios sobre os conflitos entre negros e fazendeiros durante o pós-abolição. Terminado o escravismo, muitos fazendeiros e ex-escravos tentaram utilizar as mesmas estratégias que adotavam nos tempos de escravidão, mas buscando estabelecer novas formas de distinção social (ALBUQUERQUE, 2009, p. 113; FRAGA FILHO, 2006). A abolição, mesmo não sendo uma ruptura radical, representou não somente o fim de uma relação de propriedade, mas também a perda das referências fundamentais na constituição da identificação de escravos e senhores de terra. A certeza de que o mundo social não podia ser interpretado a partir do binômio senhor/escravo comprometia tanto as relações de trabalho como os vínculos pessoais e referências de autoridade. Os proprietários não apenas perdiam os trabalhadores, mas também a sua própria posição hierárquica estava em jogo. Havia todo um "lugar social” construído desde o período colonial em torno dessas duas categorias. Muitos ex-senhores, ao fim da escravidão, viram-se fora desse lugar que estruturava toda a lógica da arquitetura social. Com o fim definitivo do escravismo, portanto, foram suspensas diversas regras que balizavam as disputas de poder entre senhores/brancos e negros/subalternos (ALBUQUERQUE, 2009, p. 125-126).

Ao que tudo indica, pela data em que ocorreu o inquérito e pela sua província de procedência, Lusia foi realmente uma ex-escrava; ${ }^{14}$ mais precisamente, uma escrava que veio para São Carlos a partir do comércio interprovincial de cativos que perdurou após 1850, data em que se encerrou o tráfico negreiro Brasil-África. E, o que é mais emblemático, ela conseguiu trazer consigo, no mínimo, uma filha. Estudando o comércio interprovincial de escravos, Chalhoub (1990) analisa alguns casos de famílias que foram separadas por meio da venda de alguns de seus membros. Somente com a análise do inquérito, não é possível perceber se Lusia se separou de alguns parentes, tais como outros filhos ou até mesmo

\footnotetext{
${ }^{13}$ Essa afirmação sugere que Ozoria poderia sofrer o assédio de pessoas ligadas à família de Rocha, seja dele próprio ou de seus filhos. No inquérito descrito, Ozoria aparece como natural da Bahia, o que torna difícil a hipótese de que ela seja filha de Rocha. Durante as últimas décadas da escravidão, era relativamente comum, no oeste paulista, os senhores terem filhos(as) com suas escravas e eles serem cuidados pelas mulheres desses fazendeiros como filhos legítimos ou como afilhados. Para mais detalhes sobre esses casos, consultar Slenes (1997).

${ }^{14}$ Contudo, convém lembrar, o processo de racialização que atravessa o fim das relações escravistas colocou, aos olhos de muitos, toda a população negra em pé de igualdade, uma vez que os negros livres não mais gozavam desse adjetivo como forma de distinção social. Não apenas aqueles que haviam concretamente experimentado a condição de escravo estavam, nesse sentido, empenhados em se livrar dos estereótipos do escravismo.
} 
o companheiro, na vinda para o Sudeste. Em 1869, foi promulgada uma lei que proibia a venda separada de membros de uma mesma família de escravos, mas muitos senhores continuaram utilizando tal prática após essa data. O que parece justificar a não separação de Ozoria e Lusia, entretanto, é o fato de a primeira nunca ter sido uma escrava, uma vez que nasceu depois de 1871, data em que foi promulgada a Lei do Ventre Livre. ${ }^{15}$ Essa lei proibia a separação de ingênuos cuja mãe escrava tivesse sido envolvida em alguma venda.

Depois de se instalar com a filha em uma fazenda e conseguir firmar relações de compadrio com uma família de fazendeiros, ${ }^{16}$ Lusia possivelmente resolveu, já como liberta, sair da propriedade onde foi escrava, deixando a filha sob os cuidados dos padrinhos. Como sugere Fonseca (2004, p. 535), tais práticas não eram de forma alguma excepcionais e, entre as camadas populares, derivavam da necessidade de acionar estratégias para a sobrevivência das crianças. Contudo, a permanência de Ozoria na casa de seus padrinhos não se estabeleceu como Lusia esperava. Ao tentar salvar a filha de boatos, ela viu sua autoridade de mãe ser contestada tanto pela recusa do fazendeiro em entregá-la quanto pela rejeição de Ozoria em seguir com a mãe. ${ }^{17}$ Para quem tem conhecimento das separações causadas pelo tráfico interprovincial, o que é muito plausível no caso de Lusia, tal fato não é de pouca relevância. Ter os laços familiares rompidos segundo a vontade de senhores foi, para muitos dos escravos que migraram forçadamente para o Sudeste, uma das piores experiências do escravismo.

[...] sem dúvida, um dos aspectos mais traumáticos da escravidão era a constante compra e venda de seres humanos [...] Os negros tinham suas próprias convicções sobre o que era o cativeiro justo, ou pelo menos tolerável: suas relações afetivas mereciam algum tipo de consideração; os castigos físicos precisavam ser moderados e aplicados por motivo justo; havia maneiras mais ou menos estabelecidas de os cativos manifestarem sua opinião no momento decisivo da venda. 0 tráfico interno deslocou para o sudeste, a partir de meados do século XX, milhares de escravos que se viram subitamente arrancados de seus locais de origem, da companhia de seus familiares, e do desempenho das tarefas as quais estavam acostumados (CHALHOUB, 1999, p. 27).

Segundo Castro e Rios (2005, p. 184), o direito de não se separar da família consistiu em um dos principais pontos de luta de muitos cativos; era um dos aspectos mais comuns dentro dos ideais de liberdade forjados por distintas experiências escravas. Cinco anos apenas após a abolição, Lusia via-se, contra a sua vontade, separada da filha; agora não

\footnotetext{
$\overline{15}$ A Lei do Ventre Livre, também conhecida como “Lei Rio Branco", estabelecia, entre outras determinações, que os filhos de escravos nascidos a partir daquela data seriam considerados livres. Filhos de mães escravas, os ingênuos beneficiados por essa lei, eram obrigados a ficar sob a tutela dos senhores de suas mães ou do governo até completarem a maioridade (21 anos). Na prática, muitos escravocratas mantiveram os ingênuos nas suas propriedades, tratando-os como se fossem escravos.

16 Luiz Alberto Couceiro (2003), que estudou os quadros de sociabilidade nas fazendas cafeeiras do Sudeste durante a segunda metade do século XIX, considera não ter sido fácil aos cativos migrados do Nordeste a construção de relações de proximidade e confiança com seus novos senhores. Segundo ele, já havia toda uma rede de relações estabelecida anteriormente à chegada desses trabalhadores.

${ }^{17}$ É possível que os adotantes - relações de compadrio à parte - tenham se recusado a entregar Ozoria porque esta, com a idade de 15 anos, ajudava nas tarefas domésticas na casa de sua madrinha. A recusa da própria filha em voltar a viver com a mãe pode estar relacionada, por sua vez, ao envolvimento dela com alguém da fazenda onde então habitava, haja vista os rumores citados por Lusia.
} 
mais diretamente devido à institucionalização do escravismo, mas por causa das próprias relações interpessoais que ela mesma acreditava que seriam benéficas para o futuro da filha.

A estratégia traçada por Lusia, em deixar a filha sob os cuidados de um fazendeiro, acabou minando sua posição hierárquica dentro da própria lógica familiar que definia esta mesma estratégia. A identificação enquanto mãe, embora continuasse a fazer parte de um dado repertório discursivo, ficava distorcida quando, como no caso descrito, é a relação entre os padrinhos e afilhados que passa a fornecer o parâmetro na constituição do binômio filha(o)/ subalterna(o) e pais/superiores. Ozoria deixou claro, em seu depoimento, que a saída da casa dependia, no que diz respeito a ela, da vontade dos padrinhos e não do desejo de sua mãe. Ou seja, a referência de autoridade, no campo privado, passara a se concentrar nas relações de compadrio. A saga de Lusia na tentativa de trazer a filha de volta explicita sua busca pela retomada desse referencial hierárquico. Sua entrada em uma fazenda onde ela nem sequer trabalhava, sem qualquer tipo de permissão, é um indício de que a ex-escrava queria, a qualquer custo, retirar a filha do controle do fazendeiro. Ainda que de forma implícita, esse conflito evidencia que as tensões pós-abolição continuavam dialogando com a experiência do escravismo, embora agora com novos significados. O fazendeiro Rocha Camargo se achava no direito de exercer autoridade sobre a filha de uma provável antiga escrava, mesmo contra a vontade da própria mãe. Por outro lado, as investidas de Lusia demonstram que a liberta não considerava mais legítimas as relações da filha com os padrinhos e entendia como seu dever a desconstrução desses laços que ela mesma outrora estabelecera. Esse seu comportamento tinha impacto direto nas lutas em torno da negociação do seu novo estatuto social: ${ }^{18}$ o controle dos fazendeiros sobre a sua filha remetia a ela, muito provavelmente, lembranças do tempo de cativeiro. 0 poder de regular autonomamente as relações familiares era, entre os libertos, um dos parâmetros na demarcação da distinção entre o "tempo do cativeiro" e o "tempo da liberdade" (CASTRO; RIOS, 2005, p. 50).

O fundamental [...] é enfatizar que, para os negros, a liberdade significava, entre outras coisas, o fim de uma vida constantemente sujeita às vicissitudes das transações de compra e venda. As feridas dos açoites provavelmente cicatrizavam com o tempo; as separações afetivas, ou a constante ameaça de separação, eram as chagas eternamente abertas do cativeiro (CHALHOUB, 1999, p. 243-244).

Lusia se sentia no dever, agora como uma livre, de não deixar que os laços sociais com um ex-senhor se sobrepusessem ao seu papel de mãe. Assim, pode-se afirmar que as relações familiares eram também de relevância dentro das disputas cotidianas relacionadas aos significados políticos construídos em torno da condição de liberto/livre. ${ }^{19}$ A constituição de um ideal de liberdade passava, além da questão mais diretamente relacionada ao trabalho e à mobilidade, pelo estabelecimento de determinadas lógicas familiares, muitas

\footnotetext{
$\overline{18}$ Os estatutos sociais de cada sujeito não são fixos e nem únicos. Não se considera, todavia, que a ideia de "contingência" possa ser mecanicamente aplicada na análise da (re)construção das hierarquias de uma sociedade pós-escravista.

${ }^{19}$ Castro (1997, p. 383) chama a atenção para o fato de, finda a escravidão, muitos ex-escravos, na busca por se afastarem cada vez mais das associações com o cativeiro, estarem empenhados em se afirmarem como cidadãos livres e não como libertos.
} 
delas dificultadas, ou então até mesmo impedidas, durante a escravidão. Ao estudar as relações entre fazendeiros de café e trabalhadores negros durante o pós-abolição, Monsma (2005b) percebeu que a maioria dos conflitos entre eles não estava relacionada a questões de trabalho, mas sim à interferência dos primeiros na privacidade desses últimos. Segundo o autor, os libertos, com o intuito de se afirmarem como livres, eram muitos sensíveis a qualquer tipo de intromissão na sua vida privada. Os fazendeiros, por seu turno, encaravam esse comportamento como desobediência e desacato, o que levava, não raras vezes, a desfechos violentos.

Antes de tentar invadir a fazenda para trazer Ozoria de volta, Lusia foi procurar um juiz para que a Justiça interviesse a seu favor. A procura pela Justiça ou pela polícia, segundo Chalhoub (1999, p. 176), já não era insignificante entre os escravos durante as últimas décadas de escravismo, pois muitos recorriam a essas instituições com a intenção de protestar contra maus-tratos sofridos ou mesmo contra acordos de alforria não cumpridos. É de se acreditar que, após 1888, a confiança no Estado tenha até aumentado entre a população negra de modo geral. Contudo, essa confiança deve ser bem relativizada. Muito possivelmente, o recurso de consulta a um juiz para tentar recuperar a guarda da filha foi umas das últimas medidas a serem tomadas por Lusia. Recurso, aliás, ineficiente, haja vista que o juiz praticamente nada fez para tirar Ozoria da casa do fazendeiro. No embate entre uma ex-escrava e uma família de grandes proprietários locais, é de se acreditar que, no âmbito da Justiça, somente em casos extremos existiam chances de uma ação favorável para a primeira. O ideal de cidadania cristalizado nas recém-criadas instituições republicanas estava imerso em processos de racialização, ${ }^{20}$ o que delimitava um caráter repressivo, em relação aos negros, por parte das ações do Estado. Orientadas pela experiência adquirida no tempo de cativeiro, as alianças interpessoais com pessoas de posse permaneceram, portanto, como uma das principais fontes de sustentação social para alguns libertos. ${ }^{21}$ Os jogos de poder envoltos nessas relações, entretanto, podiam desestabilizar outras lógicas presentes no ideal de liberdade traçado por diversos negros.

\footnotetext{
${ }^{20}$ Ancorado nos preceitos biologizantes da noção de progresso gestada em fins do século XIX, o Estado republicano foi palco de uma série de políticas com viés racista. Um dos principais exemplos dessas políticas foi o projeto de subsídio à vinda de imigrantes, visando a promoção de um "embranquecimento" do país (SCHWARCZ, 1995; ORTIZ, 1982; HOFBAUER, 2003). Observa-se também, no mesmo período, uma perseguição a qualquer tipo de manifestação cultural considerada de origem africana. Para se colocar um fim às "incivilizadas" práticas que representavam a "negritude" presente em parcela da população, o Estado brasileiro aplicou, durante a virada do século XIX para o XX, uma política de repressão à capoeira, ao samba, ao candomblé, enfim, a tudo o que lembrasse a cultura afro-brasileira (ANDREWS, 2007, p. 152-158). 0 objetivo, nesse sentido, era embranquecer não somente a população, mas também a "cultura brasileira" como um todo. Sem falar das leis antivadigem apresentadas por alguns estados, cuja finalidade era combater "os vícios advindos da escravidão" (FRAGA FILHO, 2006, p. 157-159).

${ }^{21}$ Também não devem ser desprezados os vínculos mantidos com ex-escravos. Afinal, em sua última e desesperada tentativa de trazer a filha de volta, Lusia recorreu à companhia de outros libertos para entrar na fazenda onde estava Ozoria.
} 


\section{Considerações finais}

Os dois casos analisados tratam, justamente por estarem transcritos em inquéritos policiais, de situações excepcionais..22 Muitas das tensões envolvendo as sociabilidades abordadas não tiveram o mesmo fim trágico relatado nessas duas ocorrências. Tratava-se de contendas que aconteciam e eram resolvidas longe dos olhos do poder público, sem grandes repercussões. Exatamente por se ter acesso apenas a essas situações isoladas, não é possível fazer generalização a respeito da assiduidade com que as disputas materiais e simbólicas envolvendo as relações interpessoais ocorriam no cotidiano da população negra do oeste paulista.

O exame desses inquéritos, porém, possibilitou a análise de alguns dos conteúdos sociais imersos nesses conflitos. Primeiramente, percebeu-se que os recursos relacionais mantidos com pessoas de posses, constantes nas últimas décadas de escravidão, permaneceram como uma das principais fontes de auxílio para, minimamente, alguns negros em São Carlos. Tais auxílios, como se pôde perceber, variavam desde a disponibilidade de habitação até o cuidado dos próprios filhos. Essa última prática, aliás, pareceu ser uma estratégia familiar bem consolidada, cujo objetivo principal seria possibilitar melhores perspectivas de vida para os(as) filhos(as). Ela, entretanto, não deixava de estar suscetível a certos desacordos: ao operacionalizarem certas hierarquias, padrinhos poderiam entrar em choque com outros referenciais de autoridade presentes nas relações familiares que informavam essas mesmas estratégias.

A constituição dos papéis de pai e de mãe, situada no centro da própria estratégia familiar, era colocada em xeque pela gramática de poder na qual as relações de compadrio estavam inseridas. Apesar de os padrinhos reconhecerem, em tese, os laços de consanguinidade, eles se julgavam detentores de um direito adquirido sobre as crianças que acolheram, em virtude de um contrato moral tácito e prenhe de ambiguidades. Na leitura dos inquéritos, tornou-se visível que aqueles que prestavam alguma espécie de "favor" para uma família de negros tentavam, de acordo com a circunstância, manter uma relação de interferência direta nos conflitos surgidos entre pais e filhos(as). O pai e a mãe relatados nesses inquéritos, por sua vez, não aceitaram passivamente as interferências nos seus respectivos papéis familiares. Para eles, suas relações familiares estavam bem definidas e não poderiam se confundir, de forma alguma, com os laços de compadrio ou de amizade.

De modo geral, pode-se afirmar que havia códigos morais que, ao definirem determinadas normas de sociabilidade, balizavam as relações interpessoais entre negros e seus compadres/ amigos. A afirmação desses códigos, por seu turno, passava também pela busca de um distanciamento cada vez maior das associações com um estatuto social semelhante ao

\footnotetext{
22 Recorde-se aqui que, metodologicamente, a seleção de casos pode tomar como critério o interesse teórico (e não a representatividade). Os casos analisados, exatamente porque configuram situações únicas ou polos extremos, podem ser decisivos ao avanço da teoria e do conhecimento (RAGIN, 1992, p. 222). Exemplos de tal opção podem ser encontrados em Wright (1985), ao comparar estrutura e consciência de classe na Suécia e nos Estados Unidos, ou em Geertz (1971), ao observar práticas islâmicas no Marrocos e na Indonésia.
} 
de cativo. A liberdade em poder mediar a trajetória dos filhos, mesmo se isso significasse o afastamento em relação a eles, era um aspecto do maior interesse para os negros que ainda conviviam com as lembranças do que era ser escravo. Entregar os "cuidados” de um(a) filho(a) seria uma decisão que deveria partir dos próprios pais e, como observado, uma decisão que poderia ser mudada a qualquer momento, dependendo do decorrer das interações entre filhos e padrinhos. As relações interpessoais tecidas por alguns negros durante o pós-abolição estavam, nesse sentido, constantemente sob tensão. Se, por um lado, elas constituíam uma das principais (dentre as poucas) bases de obtenção de recursos materiais e simbólicos para este grupo, também faziam parte de um processo de renegociação de certas identificações e hierarquias.

Os filhos também ficavam em uma situação complicada ao verem seus pais e padrinhos duelando pela autoridade sobre eles. Chamados para depor, eles tiveram que se posicionar frente a esses conflitos e escolher um lado para apoiar. Esse apoio, por seu turno, dependia da situação em que esses jovens se encontravam e também da intensidade dos vínculos que mantinham com seus pais e com seus padrinhos. Por estar com 20 anos, trabalhando e na eminência de ver o pai na cadeia, Sebastião Sampaio preferiu defendê-lo nos depoimentos que prestou junto à polícia e ao Juiz. Porém Ozoria Conceição, que com 15 anos parecia vislumbrar uma condição melhor na casa de seus padrinhos fazendeiros do que se estivesse com sua mãe, assim como aparentava estar um pouco distante em relação a essa última, optou por não apoiar as decisões de Lusia. Para esses jovens, os quais já nasceram livres, as separações familiares ocasionadas pelo comércio de escravos pareciam não causar tanta aflição. Os processos de inferiorização a que eles estavam sujeitos já eram distintos daqueles vivenciados pelos seus pais.

\section{Referências}

ALBUQUERQUE, W. 0 jogo da dissimulação. Abolição e cidadania negra no Brasil. São Paulo: Companhia das Letras, 2009.

ANDREWS, G. R. Negros e brancos em São Paulo. Bauru: Edusc, 1998.

América afro-latina, 1800-2000. São Carlos: Edufscar, 2007.

ARIÈS, P. História social da criança e da família. Rio de Janeiro: Guanabara Koogan, 1981.

AZEVEDO, C. M. M. Onda negra, medo branco: o negro no imaginário das elites, século XIX. São Paulo: Annablume, 2004.

BACELLAR, C. de A. P. Os compadres e as comadres de escravos: um balanço da produção historiográfica brasileira. In: XXVI SIMPÓSIO NACIONAL DE HISTÓRIA. Anais... São Paulo, julho de 2011.

CAULFIELD, S. Em defesa da honra. Moralidade, modernidade e nação no Rio de Janeiro (1918-1940). Campinas: Editora da Unicamp, 2000.

CASTRO, H. M.; RIOS, A. M. Memórias do cativeiro: família, trabalho e cidadania no pós-abolição. Rio de Janeiro: Civilização Brasileira, 2005.

Laços de família e direitos no final da escravidão. In: ALENCASTRO, L. F. de (Org.). História da vida privada no Brasil Império: a corte e a modernidade. São Paulo: Companhia das Letras, 1997, p. 337-384. 
Das cores do silêncio: os significados da liberdade no Sudeste escravista - Brasil, século XIX. Rio de Janeiro: Arquivo Nacional, 1995.

CHALHOUB, S. Trabalho, lar e botequim. O cotidiano dos trabalhadores no Rio de Janeiro da Belle Époque. Campinas: Editora da Unicamp, 2001.

. Visões da liberdade. Uma história das últimas décadas da escravidão da corte. São Paulo: Companhia das Letras, 1990.

COOPER, F.; HOLT, T.; SCOTT, R. Além da escravidão: investigação sobre raça, trabalho, e cidadania. Rio de Janeiro: Civilização Brasileira, 2005.

COUCEIRO, L. A. A disparada do burro e a cartilha do feitor: lógicas morais na construção de redes de sociabilidade entre escravos e livres nas fazendas do Sudeste, 1860-1888. Revista de Antropologia, v. 46, n. 1, p. 41-83, 2003.

ESTEVES, M. de A. Meninas perdidas. Os populares e o cotidiano do amor no Rio de Janeiro da Belle Époque. Rio de Janeiro: Paz e Terra, 1989.

FERNANDES, F. A integração do negro na sociedade de classes. São Paulo: Ática, 1978.

FONSECA, C. Crianças em circulação. Ciência Hoje, v. 11, n. 66, p. 33-38, 1990.

Ser mulher, mãe e pobre. In: PRIORE, M. del (Org.). História das mulheres no Brasil. São Paulo: Contexto e Unesp, 2004, p. 510-553.

FRAGA FILHO, W. Encruzilhadas da liberdade. História de escravos e libertos na Bahia (1870-1910). Campinas: Editora da Unicamp, 2006.

GEERTZ, C. Islam observed: religious development in Morocco and Indonesia. Chicago: Chicago University Press, 1971.

HOFBAUER, A. O conceito de 'raça' e o ideário do 'branqueamento' no século XIX - bases ideológicas do racismo brasileiro. Teoria \& Pesquisa, n. 42 e 43, jan./jul. 2003.

HOLLOWAY, T. Imigrantes para o café: café e sociedade em São Paulo, 1886-1934. Rio de Janeiro: Paz e Terra, 1984.

LARA, S. H. Campos da violência: escravos e senhores na capitania do Rio de Janeiro, 1750-1808. Rio de Janeiro: Paz e Terra, 1988.

MEDEIROS, S. Resistência e rebeldia nas fazendas de café de São Carlos. Dissertação (Mestrado). Universidade Federal de São Carlos (UFSCar), 2005.

MONSMA, K. Histórias de violência: inquéritos policiais e processos criminais como fontes para o estudo de relações interétnicas. In: TRUZZI, O.; DEMARTINI, Z. de B. F. (Orgs.). Estudos migratórios: perspectivas metodológicas. São Carlos: EdUFSCar, 2005a.

. Desrespeito e violência: fazendeiros de café e trabalhadores negros no oeste paulista, 1887-1914. Revista Anos 90, v. 12, n. 21/22, p. 103-149, jan./dez. 2005b.

ORTIZ, R. Memória coletiva e sincretismo científico: as teorias raciais do século XIX. Cadernos CERU, ก. 17, 1982.

PORTES, A. Economic sociology and the sociology of immigration: a conceptual overview. The economic sociology of immigration. Essays on networks, ethnicity and entrepreneurship. New York: Russel Sage Foundation, 1995.

n. 1-24, 1998.

Social capital: its origins and applications in Modern Sociology. Rev. Sociol., v. 24, 
RAGIN, C. 'Casing' and the process of social inquiry. In: RAGIN, C.; BECKER, H. (Eds.). What is a case? Exploring the foundations of social inquiry. Cambridge University Press, 1992.

RAGIN, C.; BECKER, H. (Eds.). What is a case? Exploring the foundations of social inquiry. Cambridge University Press, 1992.

RAGO, M. Do cabaré ao lar: a utopia da cidade disciplinar, Brasil, 1890-1930. Rio de Janeiro: Paz e Terra, 1985.

SCHWARCZ, L. K. M. 0 espetáculo das raças: cientistas, instituições e questão racial no Brasil, 18701930. São Paulo: Companhia das Letras, 1995.

SLENES, R. W. Senhores e subalternos no oeste paulista. In: ALENCASTRO, L. F. História da vida privada no Brasil Império: a corte e a modernidade nacional. São Paulo: Companhia das Letras, 1997, p. 233-290.

Na senzala, uma flor. Esperanças e recordações na formação da família escrava - Brasil, Sudeste, século XIX. Rio de Janeiro: Nova Fronteira, 1999.

TRUZZI, O. São Carlos: café e indústria, 1850-1950. São Carlos: EdUFSCar, 2000.

TRUZZI, O.; BASSANEZI, M. S. População, grupos étnico-raciais e economia cafeeira: São Carlos, 1907. Revista Brasileira de Estudos de População, v. 26, n. 2, p.197-218, 2009.

VANGELISTA, C. Os braços da lavoura: imigrantes e "caipiras" na formação do mercado de trabalho paulista (1850-1930). São Paulo: Hucitec, 1991.

\section{Autores}

Rogério da Palma é doutorando do Programa de Pós-Graduação em Sociologia da Universidade Federal de São Carlos - UFSCar, mestre em Sociologia pela UFSCar e bolsista da Fapesp.

Oswaldo Mário Serra Truzzi é doutor em Ciências Sociais pela Universidade Estadual de Campinas Unicamp. Professor associado 4 da Universidade Federal de São Carlos - UFSCar e bolsista PQ/CNPq.

\section{Abstract}

The post-abolition period in Brazil and its dynamics of sociability: family logic and interpersonal relationships in western São Paulo State coffee-producing regions

Taking as its focus the municipality of São Carlos, one of the main centers of the coffee economy in the West of the State of São Paulo in the late 18th and earlier 19th centuries, this paper examines tensions present in interpersonal relationships between black individuals, on the one side, and plantation owners and small landowners, on the other. By analyzing the documents of two police investigations of the time, it was seen that these relationships were mediated by moral codes which, in turn, determined certain rules of sociability. When these codes were violated, situations of conflict arose. It can be argued that, although, after abolition, proximity to wealthy persons was a major source of material and symbolic resources for the black population, the power relations underlying these relationships nonetheless produced identifications and hierarchies enclosed within family circles. In general, it is believed that the power struggles in those interactions may be related to the renegotiation of certain forms of social differences in the wake of the end of slavery.

Keywords: Slave families in post-abolition. Family hierarchies. Sociability. Coffee economy. São Paulo State. 


\section{Resumen}

La post abolición y sus dinámicas de sociabilidad: lógicas familiares y relaciones interpersonales en el oeste cafetalero de São Paulo

Con foco en el municipio de São Carlos, uno de los principales centros de la economía cafetalera del oeste paulista desde fines del siglo XIX hasta el XX, el artículo analiza las tensiones presentes en las relaciones interpersonales tejidas entre los negros, por un lado, y los hacendados y pequeños propietarios rurales por otro. Por medio de la lectura de dos investigaciones policiales de la época, se puso de manifiesto que esas relaciones eran mediadas por determinados códigos morales que, a su vez, delimitaban determinadas normas de sociabilidad. Cuando se rompían algunos de estos códigos, las situaciones de conflicto se potenciaban. Se puede afirmar que, si la proximidad con personas pudientes todavía era, para la población negra del periodo post abolición, una de las principales fuentes para obtener recursos materiales y simbólicos, las relaciones de poder presentes en estos vínculos no dejaban de producir polémicas en lo que se refiere a las identificaciones y jerarquías del ámbito familiar. En general, se cree que las disputas de poder presentes en dichas interacciones pueden estar relacionadas a la renegociación, ocasionada por el fin de la esclavitud, de determinadas formas de distinción social.

Palabras clave: Familia esclava. Post abolición. Jerarquías familiares. Sociabilidades. Economía cafetalera. Interior de São Paulo. 
